\title{
Benih Mardeka in the Political Movement in East Sumatra, 1916-1923
}

\author{
*BUDI AGUSTONO \\ KIKI MAULANA AFFANDI \\ JUNAIDI \\ Department of History, Faculty of Cultural Sciences, University of Sumatera Utara, \\ Medan, Indonesia \\ *Corresponding author: budi.agustono@usu.ac.id
}

Published online: 29 October 2021

To cite this article: Budi Agustono, Kiki Maulana Affandi and Junaidi. 2021. Benih Mardeka in the political movement in East Sumatra, 1916-1923. KEMANUSIAAN the Asian Journal of Humanities 28(2): 135-157. https://doi.org/10.21315/kajh2021.28.2.6

To link to this article: https://doi.org/10.21315/kajh2021.28.2.6

\begin{abstract}
This study aims to explain the movements, relationships and roles of Benih Mardeka newspaper in the political movement in East Sumatra from the period 1916 to 1923. Political movements took place as a result of rapid developments in the early 20th century in East Sumatra into a prosperous plantation area. The movements were carried by organisations delivered through propaganda tools or media, namely newspapers. One of the newspapers that loudly voiced national movement and nationalism in East Sumatra was Benih Mardeka newspaper, which began to appear in 1916. This study uses historical methods that include heuristic, source criticism, interpretation and historiography. The results showed that many articles in Benih Mardeka frequently criticised the issues of colonialism and capitalism. Meanwhile, the poor life of plantation workers became propaganda material for Benih Mardeka in criticising colonial and selfgovernment as well as capitalists, namely plantation companies. Benih Mardeka was also a mouthpiece or tool for Sarekat Islam in conveying the idea of nation and nationalism. Hence, it can be concluded that Benih Mardeka consistently gave the voice of national movement and nationalism in the political movement and the press in East Sumatra.
\end{abstract}

Keywords and phrases: Benih Mardeka, East Sumatra, labourers, political movement, press

\section{Introduction}

Entering the 20th century, significant changes took place in the order of society in the Dutch East Indies. This phenomenon led to an increase in the flow of thought about nationalism and movement to distinguish "the coloniser" from 
"the colonised". This situation was inevitable due to policies implemented by the colonial government including ethical politics. These policies, especially education, were like two sides of the same coin for the colonial government. On the one side, the colonial government expected that ethical politics could have an impact on meeting the needs for the smooth practice of colonialism such as educated resources for low-government employees. On the other side, ethical politics also gave rise to educated groups that brought thoughts and national movements, which flourished in the early 20th century.

This educated group then opened their eyes and initiated the emergence of movement organisations, which later served as pioneers of the movement that demanded independence (Van Niel 1984). One of the movement organisations that had a mass base in the Dutch East Indies was Sarekat Islam. Sarekat Islam not only brought the ideals of nationalism for unity but also launched a campaign on inequality and the social welfare of the population, immediately gaining space and mass. Sarekat Islam used the majority of the indigenous population, Islam, to gain mass not only in Java but also in other regions (Elson 2007, 248-250). Although the movement was centred in Java at first, it further developed in other regions of the Dutch East Indies.

The early national movement came along with the thought and ideas of those educated groups. Conveying such thoughts and ideas was inseparable from the role of the media and the press. The press and national movement could not be separated from each other. The press or media could be used as a mouthpiece or a tool to give voice and interests to organisations or movements in conveying ideas of nationalism (Hoogerwerf 1990, 142-143). At that time, the press, as a propaganda tool or media to criticise the colonial government, was considered a powerful and effective way to bring the seeds of nationalism.

The seeds of nationalism grew along with the mobility of goods and population, the bureaucratic needs of the colonial state and the spread of modern education in the Dutch colonial state. This development did not only occur in Java as the centre of the Dutch colonial government but also in East Sumatra. East Sumatra as a region that had developed rapidly since the early 20th century in terms of economy and population mobility had become a fertile ground for the development of the press and newspapers in search of a national identity (Samri 2011, 185186). Those factors were intertwined with the use of Malay as a national identity. The intellectual elite who brought the seeds of nationalism found momentum in the discrepancy between classes within the structure of colonial social order. The awareness of the intellectual elite was interconnected with the increasing knowledge of nationalism thought. 
One of the media or press that brought the seeds of nationalism and conducted propaganda besides being considered advocating the interests of the lower classes was Benih Mardeka newspaper. The name and motto of Benih Mardeka newspaper certainly show how progressive this newspaper was in bringing the seeds of nationalism and movement in the Dutch East Indies, especially in East Sumatra. According to Mohammad Said (1976), Benih Mardeka was the first newspaper in Indonesia that used the word "independence" and pioneered the nationalist movement and the voice of the independence movement, especially in East Sumatra. This was also evident from the motto of this newspaper, Orgaan oentoek Menoentoet Keadilan dan Kemerdekaan (Said 1976, 83).

Benih Mardeka newspaper had brought a nationalist movement at that time and played a significant role in propaganda about anti-colonial sentiments, thus became a pioneer in the development of a comprehensive nationalism (Van Langenberg 1976). Together with Sarekat Islam, Benih Mardeka newspaper made a movement focusing on issues of democratic reform and economic problems that affected workers and farmers as well as playing a prominent role in stopping arbitrary clearance of plantations in East Sumatra (Reid 2012, 91).

Benih Mardeka newspaper and Sarekat Islam were means or instruments used by the intellectual elites in fighting for the reform and advocacy movement in East Sumatra. East Sumatra, which at that time was cultuurgebied (plantation area), was a fertile ground for propaganda about nationalism and political movements. This was inseparable from the situation in East Sumatra that was full of colonialism practices, poor relationship between employers and workers, giving birth to what was called poenale sanctie (penal sanction), as well as the discrepancy between the colonised and the colonial as well as local-autonomous authorities.

\section{Methodology}

This study employed the historical method, which is an attempt to reconstruct past events. The reconstructed events are those that had been thought, said, done and experienced by human beings. To reconstruct a historical event, Garraghan (1957) emphasised some systematic principles and a set of rules for collecting the historical sources effectively, evaluating them critically and presenting a written synthesis or results.

There are two types of historical sources: primary and secondary. Primary sources, as used in this study, were Dutch colonial archives derived from the National Archives of the Republic of Indonesia collection in Jakarta. 
Meanwhile, the secondary sources were in form of documents and compendiums of Dutch East Indies government press, Benih Mardeka newspaper, De Sumatra Post newspaper, Mardeka newspaper and Soeara Djawa newspaper, along with books and journals obtained from the National Library of the Republic of Indonesia collection in Jakarta.

The next phase is the historical source criticism. The purpose of source criticism is to investigate and obtain the originality and credibility of the sources used in a study. Through this technique, the facts can be found in those sources. Those facts will later be interpreted by the researcher into analysis and synthesis. This present study involved the use of qualitative analysis.

The final phase of this process is historiography based on the previous steps that have been done in advance. The process of presenting the data in a narrative form used the descriptive-analytical method. Therefore, the processed data are described in-depth and focused on by following the causality and chronological principles.

\section{Socio-Political Movement and the Press in East Sumatra}

East Sumatra is a region that at present belongs to the province of North Sumatra. Its region includes Langkat, Deli Serdang, Batubara, Asahan, Simalungun and Karo. In the colonial period, this region was called Residentie Oostkust van Sumatra (the East Coast Residency of Sumatra). This area could not be separated from the development of plantations. In 1863, Jacobus Nienhuys came to this region to introduce the industrial economy of the plantations. Afterwards, during the Dutch colonial period in East Sumatra for three fourth of a century, this region was rapidly developed as a cultuurgebied. Moreover, Thee Kian Wie mentioned that the development of plantations in East Sumatra was unique and unrivalled in any region of the Dutch East Indies (Wie 1977, 1-4). Such rapid and drastic developments had affected various changes that were so complex, including regional, demographic, economic, social, political and cultural aspects.

The changes affected the socio-cultural conditions of the population in East Sumatra. In terms of demography, for example, there was a change in the increase of migrants exceeding the local population, namely Malay, Karo and Simalungun. The migrants consisted of Europeans, Chinese, Indians and other bumiputera (son of the soil) such as Java, Minangkabau, Mandailing, Aceh, Toba and Banjar (Loderichs et al. 1997, 33-34). These changes occurred as a result of the industrial economy of the plantation. 
Demographic changes and population mobility mainly occurred in large cities as the industrial centre of plantations. A plantation centre in East Sumatra, Medan City showed a very significant population growth (Miksic 1989, 21-22). From 1905 to 1920 , the population in Medan increased by three times, from 14,250 to 45,248 people. In 1920 , the ratio of bumiputera and foreign residents was also almost balanced, involving 3,128 European residents, 18,297 East Foreign residents and 23,823 bumiputera residents. Among the 23,823 bumiputera residents, more than half of them were migrants from outside Sumatra, approximately 12,000 from Java and 2,000 from non-Java, while the remaining was dominated by those from Tapanuli and Minangkabau (Volker 1923, 14-15).

Of the population groups who came to East Sumatra, they were dominated by labourers working on plantations. Most of them were from Java and China. Soon, their number continued to increase along with the development of plantations. Moreover, there were intellectual groups who migrated to East Sumatra and spread the concept and ideology of nationalism in this region. This intellectual group received Western education and mostly worked as employees of the colonial government, lawyers, doctors and journalists (Van Langenberg 1976, 84).

Such massive migration and demographic changes resulted in the emergence of interests in many groups of residents. In 1916, there were already various associations in this region, consisting of associations of Chinese, Indian, Japanese and bumiputera residents. They were Sarekat Islam Medan, Boedi Oetomo, Sarekat Islam Delispoor, Sarekat Islam Tapanoeli, Sarekat XII Goeroe, Debating Roh Kita, Medan Setia, Opiumregie-Bond, Rekso Sengkono, Deli Medan Sumatra Hindu Dharma Sargam, Deli Hindu Sabha and Nippondjin Kyokai (Schadee 1917, 53).

To show their existence and to voice their interests, tools or media including the press were used by some groups in East Sumatra, which began to develop in the late 19th century. Broadly speaking, there were two major differences in media or press in East Sumatra. The first served as a tool to support and perpetuate the power and interests of plantation companies and colonial governments. The second was to spread the seeds of nationalism and a tool to criticise the business activities of plantation capitalism and the policies of the colonial or self-governing authority in East Sumatra.

The changes and developments not only took place in the industrial economy of the plantation but also led to the rise of the educated group. The great number of educated modern elite groups had increased their awareness of the need for advancement and prosperity for their people. Such awareness was then 
realised by establishing a movement organisation using the press as a means to communicate ideas, dreams and programmes that supported the movement. Thus, the first decade until the first quarter of the 20th century could be said as the period of the establishment of various socio-cultural, religious and political movement organisations in Indonesia. As a result, the press emerged as a "mouthpiece" of the organisations of such movements (Suwirta 1999, 87).

In the beginning, the press in East Sumatra was employed as a tool to voice the interests of plantation companies. The first newspaper published in Medan was Deli Courant. The Deli Courant was founded by Jacques Deen, a Dutchman. This newspaper first appeared on 18th March 1885, published twice a week on Wednesday and Saturday as a tool for the plantation companies in voicing their interests. Moreover, the bumiputera press at that time called Deli Courant a "tobacco newspaper". Another influential and widely-recognised newspaper owned by Europeans was De Sumatra Post. This newspaper was published by a publishing company, J. Hallermann \& Co., in 1899. It was recorded that several Dutch figures served as the editors, namely J. van den Brand, A.J. Lievegood and Vierhout (Said 1976, 33-34). In voicing its interests, it was said that this newspaper was more independent and progressive than its predecessor.

Another newspaper was Pelita Andalas, which was owned by the Chinese and initially published by Drukkerij Andalas in 1911. In 1913, its name changed to Andalas, published by Sumatraasche Handelsdrukkerij, Medan. This newspaper appeared every Tuesday, Thursday and Saturday. Like most Chinese-owned newspapers, this newspaper puts more emphasis on advertising than news. All of its editorial members were Chinese (Adam 2003, 253).

In 1910, the first Malay language newspaper in Medan was published and managed by bumiputera. This newspaper was Pewarta Deli whose editor in chief was Dja Endar Moeda. Pewarta Deli was published by a company called N.V. Sjarikat Tapanuli. The majority of the editorial board were Mandailing and Angkola people. Previously, Malay-language newspapers had been published in Medan, namely Pertja Timoer in 1902. However, this newspaper was published by a company that printed the Sumatra Post; thus, many foreign news references were taken from the news of Sumatra Post (Adam 2003, 250-251). According to Djamaluddin Adinegoro, in 1902, Pertja Timoer newspaper was led by Sutan Malenggang and then replaced by Mangaradja Salambuwe. In 1905, Mangaradja Salambuwe passed away and the leadership of this newspaper turned to Moses. This newspaper did not last long as it did not publish any more news in 1908 (Serikat Perusahaan Surat Kabar 1958, 233). 
Pewarta Deli later emerged as the first national newspaper in Medan. Its echo was not only felt by local people but even attracted readers from the outside of the Dutch Indies. This was because the newspaper was commercially oriented and managed to meet the needs for information related to plantations and investment opportunities in this region. Interestingly, Pewarta Deli's shares were managed and monopolised by people from Mandailing and Angkola-Sipirok, who were known to be good at business (Adam 2003, 251).

The press movement in East Sumatra was initially inadequate compared to similar movements in Java in the 1910s (Schadee 1917, 52). The press movement accommodated by the Chinese and local residents, namely Andalas and Pewarta Deli newspapers, did not produce many articles related to propaganda about the welfare of the indigenous population, education and the goodness for the society. This was because the newspapers were still commercially oriented (Adam 2003, 253-254).

Although it seemed that the beginning of the development of the press in East Sumatra did not bring movement and propaganda related to nationalism at first, the national and political movements developed very dynamically in the later stages. Population mobility, rapid information and new ideologies that entered the cities resulted in the emergence of a sense of national identity. This identity was a sense of Indonesian-ness that developed rapidly before the 1920s due to the use of many Indonesian newspapers in East Sumatra. This then became an antithesis of associations or organisations that emerged during that time.

\section{Benih Mardeka and the Press Movement}

The development of the movement organisation was interconnected with the flourishing of the press or media that conveyed the organisation's ideas. The presence of newspapers was an important element not only in communicating ideas, dreams and programmes that supported the movement but also in disseminating ideas of nationalism. This was based on the use of Indonesian as a national identity. The use of Indonesian in newspapers strengthened a sense of national identity, making the role of newspapers to be very important. The notion of nationalism grew mainly in a region in which population mobility was dynamic, so it created a fertile ground for propaganda by the movement organisations.

From the late 19th century until the 1920s, East Sumatra was one of the areas of the Dutch East Indies with a high rate of population growth and mobility. One of the factors was the existence of plantations where many migrants from outside 
the East Sumatra region came to this area to seek their fortune. The large number of migrants living in this area resulted in the East Sumatra region eventually getting inhabited by a heterogeneous population with various interests. The world of press and political movements in East Sumatra, for instance, were brought by scholars from West Sumatra and Tapanuli to cities in East Sumatra. It was stated by Anthony Reid that the Indonesian nature of the cities in East Sumatra had made various national political issues a part of the conversation of the Sumatran population. However, the many interests among these scholars made it difficult to expand influence and movement to the Karo, Simalungun and plantation workers groups who were strictly controlled by their exclusive nature (Reid 2012, 89-92).

The press movement in East Sumatra began to find its momentum when nationalist ideologies were brought by associations and organisations. East Sumatra was a fertile ground for propaganda related to life inequality and other social problems that concerned the lives of many people. These problems then became a matter of debate in the press and divided the press into two blocks in East Sumatra; the pro-colonial and plantation capitalists press and the press that fought for the interests and justice of the people.

The condition of the political movement in East Sumatra was enlivened by the growth and emergence of the press or media to convey or disseminate ideas and propaganda to the wider community. As in Java, political associations in East Sumatra also had their newspapers. In East Sumatra, the Boedi Oetomo organisation owned the Soeara Djawa newspaper. Meanwhile, the movements and propaganda of Sarekat Islam were widely voiced by Benih Mardeka. The development of the press in East Sumatra was greatly affected by the development of the Malay language in this region. Later becoming the embryo of the Indonesian language, the Malay language became a political effort to create and unite a national identity, which was united by the use of the Indonesian language.

Benih Mardeka was a newspaper that showed concern for social and political conditions in the Dutch East Indies, especially in East Sumatra. This newspaper was first published on 20th November 1916, by a publisher, N.V. Handel Maatschappij Setia Bangsa before a notary in October 1916 (Said 1976, 82). This company also published Soeara Djawa newspaper, an organ or tool for the propaganda of the Boedi Oetomo organisation. Benih Mardeka and Soeara Djawa were published in the same year, 1916. This was the year when the nationalist elements and nationalism began to influence the East Indies, especially 
East Sumatra and the colonial government in East Sumatra still did not pay attention to the development of nationalism and press movements, especially the press owned by bumiputera (Schadee 1917, 54).

Based on information from the Kroniek 1916 issued by Oostkust van Sumatra Instituut, the press movement in East Sumatra in 1916 was relatively ordinary and very far compared to the press movement in Java (Schadee 1917, 52). The development and movement of the press were affected by the development of the organisations at that time. It was noted that four organisations played important roles in the rise of the Indonesian press, namely Boedi Oetomo, Sarekat Islam, Indische Partij and the Indonesian Communist Party (Hoogerwerf 1990, 143).

The development of the press and nationalist organisations were closely related to one another. Suwirta mentioned that the press was the voice and weapon of the nationalist group and its movement organisation. The press functioned as a means of communicating ideas, ideals and programmes through meetings and congresses of the movement organisations (Suwirta 1999, 87-88). Boedi Oetomo owned newspapers called Retnodhoemilah, Darmokondo and Goeroe Desa. Sarekat Islam owned Oetoesan Hindia, Kaoem Moeda, Sinar Djawa and Sarotomo. Indische Partij owned De Express, Het Tijdschrift, Tjahaja Timoer and Persatoean Indies newspapers. The names of these newspapers reflected the views and aspirations of the editors and were adapted to the spirit of the times at that time (Said 1987, 245-252; Suwirta 1999, 87).

In general, the political movement in East Sumatra was very dynamic. However, several organisations had shown different directions and thoughts, which included Boedi Oetomo, Sarekat Islam, Sarekat Tani and Sarekat Kaoem Boeroeh. As a result, debates on ideological differences and interests took place among these organisations. For example, the debates between Boedi Oetomo based on the Javanese ethnic group and Sarekat Islam based on Islam. This was similar to other organisations that had their own bases and principles (Anonymous 1920).

Benih Mardeka made a breakthrough in the development of the press, which was initially more commercially oriented. It loudly voiced conditions and issues concerning justice and demanded equality in obtaining rights, especially in East Sumatra. In one of its publications, Benih Mardeka explained its definition as a seed that would be disseminated to achieve freedom and independence. Meanwhile, the newspaper slogan, Orgaan oentoek Menoentoet Keadilan dan 
Kemardekaan was intended to be a newspaper that brought the flow and space to achieve independence and jointly attempted to achieving such independence (Benih Mardeka 1918a).

In expressing criticisms about colonialism and capitalism, it can be said that the contents of Benih Mardeka were quite sharp in their time. It also followed the development of the press in Java and quoted them in this newspaper. Moreover, there was a separate rubric or corner as a place to express politics. The corner was entitled "Boeal" in which an author always wrote under the pseudonym of Meong. The corner was very popular for readers because the criticism was political but was packaged in a humoristic style (Said 1976, 83).

If observed from the early days of the establishment of the Benih Mardeka, it was impressive that this newspaper became an organ or tool of the Sarekat Islam organisation in East Sumatra. Although it was not explicitly stated that this newspaper was a tool of Sarekat Islam, its movement and struggle were voiced by this newspaper. This was because most leaders of Benih Mardeka were important figures in Sarekat Islam in East Sumatra.

The first chief editor of Benih Mardeka was Mohamad Samin, a Minangkabau who also served as a Commissioner of Sarekat Islam for the East Sumatra region. In addition, Mohamad Joenoes, a deputy chairman of the Asahan branch of Sarekat Islam, served as the editor. Furthermore, Tengkoe Radja Sabaroedin was appointed as the director to manage the company. He was the President of the Sarekat Islam of Medan Deli branch who still had relations with Deli noblemen (Said 1976, 82-83).

Benih Mardeka changed its leadership several times. Mohamad Samin no longer served as the chief editor. On 3rd April 1918, his name was not found. Meanwhile, the chief of the company and chief editor positions were taken over by Tengkoe Radja Sabaroedin. The position of the editor was still held by Mohamad Joenoes (Said 1976, 83-86). In the issue of 1st August 1918, the R.K. Mangoenatmodjo appeared as editor under Mohamad Joenoes. Previously, R.K. Mangoenatmodjo was the editor of Soeara Djawa newspaper. In March 1919, Abdoel Moeis, one of the leaders of Central Sarekat Islam, was recorded as the editor above Mohamad Joenoes. In May 1919, Parada Harahap appeared as editor but did not last long. In August, all the names disappeared and only Mohamad Joenoes was left. According to Mohamad Said, several changes in the leadership of Benih Mardeka reflected an uncomfortable situation in the newspaper (Benih Mardeka 1918b). 
Not only did the leadership experience change, but the name of the newspaper also changed several times. The name Benih Mardeka was used at the beginning of the issue until 31st March 1920. In the issue of 1st April 1920, the word Benih was removed, leaving only Mardeka (Mardeka 1920a). This lasted until January 1921. In the issue of January 1921, the name Benih Mardeka returned and lasted until 1923. At the beginning of 1924, there was a merging publication between Benih Mardeka and Warta Timoer under the name Benih Timoer. There were no clear reasons related to the change of those names (Volkslectuur 1920-1931, 4).

In voicing and advocating the interests of the people against capitalism, Benih Mardeka played an important role in disseminating news related to the strike of railway labourers at N.V. Deli Spoorweg Maatschappij. The incident took place in early September 1920 (Mardeka 1920b). The labour strike was well organised and arranged. Mohamad Samin, at the time of the strike serving as editor of Mardeka newspaper, was Voorzitter Raad van Advies (Chairman of the Strike Advisory Board). Although it could be said that the strike was failed in the end, N.V. Deli Spoorweg Maatschappij was estimated to suffer a loss of $f 200,000$ (Said 1976, 89). ${ }^{1}$ It was such a huge loss at that time. The strike organised by the railroad labourers was then followed by strikes from other companies, although relatively small in scale and intensity that did not last long, such as the strike of Medan water company workers, the strike of Pangkalan Brandan oil workers and the strike of railway company workers in Aceh (Mardeka 1920c).

The strike movement organised by the N.V. Deli Spoorweg Maatschappij workers was in line with that in Java. These movements were a result of the increase of communist influence in the Dutch East Indies since the end of the second decade of the 20th century. The communist movement quickly spread throughout the Dutch East Indies. The labour strike at N.V. Deli Spoorweg Maatschappij was finally muted after a meeting between strikers and the board of directors of the N.V. Deli Spoorweg Maatschappij. The meeting agreed on increasing wages, hence finally stopping the strike (Blumberger 1931, 135-136).

The labour strike movement had been planned for a long time and Mohamad Samin served as its advisor and acted in his capacity as a commissioner of Sarekat Islam in East Sumatra. In 1918, Mohamad Samin received many inputs, suggestions and questions related to the strike, as the impact of the strike in Java. According to him, a good strike must be organised orderly and carefully. In other words, the strike had to be well consolidated (Anonymous 1918). 
Benih Mardeka played a very vital role in the movement and spread of national awareness and nationalism. Despite the friction between the bumiputera press figures related to the national movement, Benih Mardeka was able to make a breakthrough and loudly voice the seeds of independence. The dynamic political movement in East Sumatra increasingly enriched the identity of Indonesian-ness for movement leaders, especially figures in Benih Mardeka newspaper.

\section{Benih Mardeka and Sarekat Islam}

It is undeniable that Benih Mardeka was closely related to the Sarekat Islam organisation in East Sumatra. Although not explicitly stated as an organisational tool in East Sumatra like Boedi Oetomo's Soeara Djawa, the leaders who led Benih Mardeka at the beginning were important figures in the Sarekat Islam organisation. This had a direct impact that the voice of Benih Mardeka certainly brought the direction and movement of the organisation.

Sarekat Islam is an Islamic-based organisation that was very influential from 1910 to the 1920 s. Korver $(1985,1)$ stated that one of the political movements that developed very prominently and deserved attention before World War II was Sarekat Islam. This organisation was officially established on 11th November 1912 in Solo, Central Java, which was transformed into a new force that gave birth to many movements and nationalist figures. Sarekat Islam claimed that at its peak had up to two million members throughout the Dutch East Indies (Bezemer 1921).

Four years after the establishment, the influence of this organisation was strongly felt in the political stage of the Dutch East Indies. The propaganda movement that touched the lower classes and defended the interests of the bumiputera from the oppression of Europeans made this organisation very popular in society (Rutgers 1939, 64-66). In 1916, it was estimated that its members reached 800,000 and doubled in the following year (Kahin 1995, 87). Several analyses also stated that Sarekat Islam was the first mass organisation in Indonesia.

Sarekat Islam then established its branches in the Dutch East Indies regions, including East Sumatra. Developing into plantation areas in the early 20th century, East Sumatra emerged as a new unique region. The plantation industry invited "outsiders" who ultimately dominated and exceeded the number of local residents. This then led to the spread of outside influences such as nationalist ideology and nationalism. A huge discrepancy between the life of "the coloniser" and "the colonised" allowed Sarekat Islam to rapidly develop in this region. 
Sarekat Islam was first established in Medan, East Sumatra, in 1914. It was further developed by the establishment of branches in other cities in East Sumatra. Within two years, other branches had been established in Serdang, Langkat, Tanjung Balai, Labuhan Bilik and Tebing Tinggi (Korver 1985, 229). This organisation was spread by migrants related to the development of the plantation. They were mainly educated groups of Mandailing and Minangkabau. The groups belonged to the middle-class group in East Sumatra. In addition, the Sarekat Islam was accepted and gained many members from the Javanese ethnic group as the largest in the region. ${ }^{2}$

Sarekat Islam movement found a space to convey and channel its ideas and voices in Benih Mardeka. As explained earlier, at the beginning the newspaper was led by Sarekat Islam leaders in East Sumatra. As in Java, Sarekat Islam employed the press to convey movements that tended to be radical. In Java, Sarekat Islam employed tools or media that convey their voice such as Oetoesan Hindia in Surabaya, Sinar Djawa in Semarang, Pantjaran Berita in Betawi and Saroetomo in Surakarta (Hoogerwerf 1990, 143).

Benih Mardeka often reported the results or plans of the Sarekat Islam general meeting in various regions of East Sumatra. For example, a general meeting that would be held at the Sarekat Islam of Medan-Deli branch on 21st March 1920 would be reported by Benih Mardeka on 18th March 1920. The plans for the discussion included discussions on the 1919 report, discussion of financial reports, the upcoming election of the management board, action and movement determination, as well as meetings and propaganda for members of Sarekat Islam of Medan-Deli branch (Benih Mardeka 1920a).

Benih Mardeka also reported on the congresses of Central Sarekat Islam. In 1918, the congress in Surabaya was attended by representative of Sarekat Islam of East Sumatra, namely Mohamad Samin (De Sumatra Post 1919). In detail, Benih Mardeka described the results of the congress and representatives of the Sarekat Islam in East Sumatra. There were several resolutions and working papers conveyed by the representatives of Sarekat Islam, including those related to the problems of the life of contract labourers in East Sumatra, the discourse on the elimination of the poenale sanctie, the issue of conflict between capitalists and residents and education (Benih Mardeka 1918c). All were discussed in several issues of Benih Mardeka at that time.

Several regulations in the articles of association of Sarekat Islam in East Sumatra were also reported by Benih Mardeka, including: (1) Every month, a deliberation at branch level was held and every three months, a deliberation was held at 
regional level, (2) Conducting movements in improving people's welfare and (3) In the case of the death of Muslims, each member had to help in the form of energy and money (Benih Mardeka 1920b).

Benih Mardeka also voiced about the agenda and work programme carried out by Sarekat Islam in East Sumatra related to the people's welfare at large. Among the steps and activities of Sarekat Islam included education, law, social and politics. In education, Sarekat Islam initiated education for labourers' children on plantations, farm schools and kweekschool (teacher education schools). Sarekat Islam demanded that the colonial government took part in resolving education problems for labourers' children and took concrete steps by establishing schoolhouses and providing lessons for them. In addition, it also demanded the government to provide a separate budget related to this problem (Benih Mardeka 1920c).

Sarekat Islam also collaborated with other organisations to fight for education in East Sumatra. In Medan, Sarekat Islam and Muhammadiyah established the Muhammadiyah School using money from Sarekat Islam members of $f 1,374.32$. In addition, Sarekat Islam demanded to the plantation council that a farm school is created for $f 45,000$ (Benih Mardeka 1920b). In improving the quality of education in East Sumatra, Sarekat Islam demanded the establishment of a teacher education school from 1914, which was then realised by the government in 1919. The existence of teacher education schools in East Sumatra, precisely in Medan, would influence public education in East Sumatra, which would increase the number of Hollandsch Inlandsche School (HIS), resulting in the increased quality of public education (Benih Mardeka 1920d).

Legal issues were a matter of concern to Sarekat Islam in East Sumatra. For instance, the legal issues involving a Sarekat Islam administrator and editor of Benih Mardeka, Mohamad Joenoes. Mohamad Joenoes was tried by a court of the self-government of Deli and was imprisoned for three months for his article in Benih Mardeka. His writing satirised the Sultan of Deli regarding land disputes with Tengkoe Hadji Djahir. The article was entitled "Hewan Mengamuk" (Raging Animals). Due to injustice towards people at large, Sarekat Islam of East Sumatra, in collaboration with Sarekat Islam of Tapanoeli, Djamiatoel Moehabbah, Boedi Oetomo, Nationale Indische Partij demanded improvements in the courts based on fair law in East Sumatra (Benih Mardeka 1920e).

In social and political aspects, Sarekat Islam paid great attention to issues related to the demand for the abolition or liberation of forced labour, demanding a fair distribution of land to the people and the improvement of the life of plantation 
labourers. The demand for the abolition of forced labour in East Sumatra was directly aimed at the volksraad (people's council) so that the people in East Sumatra, both the sultanate and gubernemen (the government), were not burdened with forced labour. The volksraad through a letter dated 16th November 1918 considered this matter. Another effort made by the leaders of the Sarekat Islam was by coming before the governor of East Sumatra and asking to abolish forced labour by considering difficult economic conditions (Benih Mardeka 1920d). The Governor of East Sumatra then decided to temporarily abolish the forced labour and the poor were not required to pay taxes of $f 12.5$. However, this did not apply to the people of the sultanate as the forced labour was considered by the sultan as a custom called adat kerahan; thus, he objected if the forced labour was abolished (Benih Mardeka 1920d).

Concerning the demand to distribute land for the people in East Sumatra, Sarekat Islam collaborated with Djamiatoel Moehabbah, Sarekat Islam Tapanoeli, Boedi Ooetomo and Nationale Indische Partij. They submitted a request to the representatives of the governor and sultanate government to make land equality between the people of the gubernemen and the sultanate. The demand also contained that the people were given legalisation concerning land rights such as land certificates. In addition, they requested that the vacant land in the forest is cultivated by the people. This request was then followed by all branches of Sarekat Islam in East Sumatra (Benih Mardeka 1920d).

\section{Advocacy to Plantation Laborers}

One of the interesting problems in the discussion of the press in East Sumatra was the life of contract labourers, especially the issue of poenale sanctie. This problem was even referred to as covert slavery or modern slavery in East Sumatra (Anonymous 1918). If observed further, this problem was discussed at the turn of the 20th century, when the brochure of van den Brand was circulated widely to the Kingdom of the Netherlands and became a polemic (van den Brand 1902). The problem of plantation labourers was a sensitive issue throughout the 20th century, leading to much debate that took place not only between the European press and the bumiputera press but also among fellow bumiputera press (Breman 1997, 239-240).

Regarding labourers on East Sumatra plantations, the Dutch East Indies government had regulated the rights and obligations of labourers and employers as stipulated in Koelie Ordonnantie 1880. The regulation stipulated working hours, wages and sanctions if violating the work rules, both for employers and workers. ${ }^{3}$ Labourers bound by these regulations were then known as contract 
labourers and will be imposed sanctions if they violated the contract called poenale sanctie (Wertheim 1987, 358-359).

The basic principle of this regulation was to protect employers from naughty labour practices. However, in practice, there were many despotic actions done by employers to their workers. Employers judged their labourers and many inequalities occurred as seen in the sanctions imposed. If labourers were sick or unable to complete their works, they would be subjected to forced labour sanctions within the period determined by the employer (Stoler 1983, 45-46).

Despotic practices and actions against workers have been carried out even before labourers work on plantations. Fraud and deception took place at the time of their recruitment, especially in poor villages in Central Java. At that time, the popular term was "labour selection". The agents or werek (selectors) persuaded prospective labourers to work on plantations with a lure of high salaries and a good life in the land of Deli (Szekely-Lulofs 1985, 9-10). Fraud and deception committed by labour recruitment agencies were often not under the supervision of the colonial government. The government sometimes allowed these practices to take place and it seemed to be a symbiosis of mutualism between agents and police of the colonial government (Benih Mardeka 1918d).

In the plantations, the life of labourers was getting worse since it was very difficult for them to get out of the trap of poverty and destitution. The plantation attempted to create a situation that labourers remained bound with the plantations. Labourers on plantations usually received wages on the 1 st and 16th of each month (Middelbare Koloniale Landbouwschool Deventer 1921, 25-26). After that, the plantations held a night market in which gambling and prostitution were allowed and opium was freely sold to workers on plantations. ${ }^{4}$ Thus, it was not surprising that there were many criminal acts committed among workers and violence on plantations with such life.

The living conditions of labourers, especially the issue of poenale sanctie, also led to debate and friction between East Sumatra press figures, both between the fellow indigenous press and the European press. Among the indigenous press leaders who debated the abolition of the poenale sanctie was Mohamad Samin with the editor of the Soeara Djawa newspaper, R.K. Mangoenatmodjo. In addition, both had conflicting views with the editors of De Sumatra Post newspaper (Anonymous 1918). 
Nevertheless, Benih Mardeka encouraged and collaborated with other bumiputera newspapers concerning the interests of the contract labourers in East Sumatra. Benih Mardeka also decided to keep up with the situation and developments of the press in Java to participate in their propaganda. The collaboration was carried out with Pewarta Deli and Soeara Djawa. Benih Mardeka and the two newspapers initiated the collection of assistance for contract labourers in which funds were managed by Sarekat Islam and Boedi Oetomo organisations (De Sumatra Post 1918).

The advocacy by Benih Mardeka for labourers in East Sumatra was given for several reasons. These included the difficulty of life and the high cost of living among labourers in East Sumatra. Sometimes, they failed to meet their daily needs with the wages they received. The following table describes the basic needs and prices for plantation workers.

Table 1. Basic needs and prices in East Sumatra in one month

\begin{tabular}{clc}
\hline No. & Basic needs of labourer & Price (in guilders, $\boldsymbol{f}$ ) \\
\hline 1 & Four bushels of rice & 2.80 \\
2 & Two bottles of kerosene & 0.20 \\
3 & One bottle of coconut oil & 0.38 \\
4 & Dried fish & 1.50 \\
5 & Salt & 0.20 \\
6 & Shrimp paste & 0.30 \\
7 & Cigarettes and matches & 0.50 \\
\hline & Total & 5.88 \\
\hline
\end{tabular}

Source: Benih Mardeka (1920c)

In advocating labourers, the leader of Benih Mardeka directly visited and observed the life of the labourers. Some of their desires and demands involved the problems of overworked hours and low wages, demand for housing from jaluran land (customary land) on the plantation and a pension system for labourers on the plantation (Benih Mardeka 1918e).

The lives of labourers on plantations were quite low due to the hierarchy and levels based on economic and social classes. These hierarchies and stratifications existed in all social and economic relations on plantations (Locher-Scholten 1992, 219). In the social stratification on plantations, there was a sharp separation between European staff, intermediaries between European staff and labourers who were commonly called foremen and labourers, the lowest class. 
The comparison of social stratification was seen in the salary received by European staff and wages received by the foremen, especially labourers who occupied the lowest structural position. After the 20th century, European staff received salaries of $f 200$ per month and would increase to $f 400$ after 6 years of work (Janssen and Bool 1939, 79). The wage of Chinese labour foreman was equal to $f 319$ per year, a senior Javanese foreman got a wage $f 258$ per year, while a Javanese foreman usually got $f 135$ (Said 1990, 92). The wage of Chinese labourers was calculated based on the number of caring and harvesting that a wage of $f 10$ was given for 1,000 tobacco trees as it used a bulk system. For a Javanese labourer who just started working, they only got a wage of $f 0.55$ per day, a Javanese labourer who had worked for a long time received $f 0.60$ per day, whereas female Javanese workers got $f 0.50$ per day (Janssen and Bool 1939, 81). In addition to wages, the payment system for labourers also used rice, which was called portion or ration (Pelzer 1985, 156).

Such low social levels and stratification were exacerbated by the poor economic life experienced by these workers. The wages of labourers on plantations were only around $f 0.35$ and if they worked in full for one month, they would receive a wage of around $f 10.50$. Of these wages, labourers had to pay instalments of debt from the money received at the beginning when signing a work contract by $f 2$. Therefore, labourers only received wages of around $f 8.50$ every month (Benih Mardeka 1920c).

From the wages of only $f 8.50$ received every month, labourers had to fulfil their basic needs by $f 5.88$. Accordingly, the remaining wage was $f 2.62$. With the remaining wages, they also had to buy clothes and pay for train fees when going to the city, among other needs. To make this worse, gambling and prostitution were also legalised in the plantations (Benih Mardeka 1920c).

The living conditions and work systems of labourers on East Sumatra plantations were very heavy and bad. The labour contract system on plantations was even referred to as "industrial slavery", which was worse than common slavery. Accordingly, not only that the condition of the working system was bad, but there was also moral degradation among the labourers as a result of the policies of the plantation companies that legalised gambling, prostitution and refused legal marriage based on religion in the plantations (Korver 1985, 121).

With the very heavy life of labourers, several resolutions were proposed in general meetings held by Sarekat Islam in East Sumatra. Benih Mardeka took part in propagating and voicing them. Some of the points that became resolutions 
and finally brought to the congress of Central Sarekat Islam in Surabaya in 1918 were as follow:

1. Abolition of poenale sanctie.

2. Labour salary standards of above $f 60$.

3. Maximum labour hours turned to eight hours.

4. Labourers who have completed their contract period may decide to terminate their employment contract.

5. Labourers who had worked for 15 years had the right to retire.

6. Labourers who wished to stay in East Sumatra were entitled to erfelijk individueel bezit (land with the right to cultivate).

7. Pregnant women labourers with the gestational age of 7 months and before 40 days after giving birth were not required to work, but their salaries still had to be paid by the plantations.

8. Every labour legal case has to be tried by a court of colonial government or landrechter.

9. All child labourers would receive education at the plantation school.

10. Gambling was strictly prohibited on plantations.

(Said 1990, 138)

The 10 demands were resulted from struggles and movements made by the press figures, especially Benih Mardeka and the Sarekat Islam organisation in East Sumatra. Thoughts and ideas in advocating the lives of workers on plantations found their momentum when Mohamad Samin delivered a speech at the general meeting of Sarekat Islam Medan-Deli on 17th February 1918. The speech condemned and imprecated acts of violence against labourers on plantations (Soeara Djawa 1918).

In his speech, Mohamad Samin explained the advent of investment and foreign capital into East Sumatra. The rapid development of plantations was aided by Javanese immigrant workers bound to work regulations called Koelie Ordonnantie. He also explained the fraud committed by labour recruitment agents, labour suffering, low wages, poor treatment of employers and punishments received by labourers popularly known as poenale sanctie. 
During his tenure as editor in chief of Benih Mardeka, Mohamad Samin often criticised regulations about coolies and bad and cruel practices of poenale sanctie (Said 1990, 137).

\section{Conclusion}

In general, this study seeks to explain the history of the Benih Mardeka newspaper as a medium for the political movement of Sarekat Islam and the press movement in the defence of labour in East Sumatra plantations from 1916 to 1923. The political movement and development of the press in the Dutch East Indies that took place were influenced by the growth of the seeds of nationalism in the early 20th century. As described earlier, the political movement and development of the press were represented by a growing organisation led by scholars. The press as a medium to convey the interests of nationalist groups served in conveying national ideas and movements. This was supported by the use of Indonesian by the bumiputera press as a search for national identity. As in Java, East Sumatra as a developing and open region with a flow of information and national seeds also experienced this. The growth of the press and newspapers was considered rapid with the interests of various groups of the population. In general, there were two blocks of interest brought by the press in East Sumatra; a press that was pro-colonial government and plantation capitalist and a press that fought for interests and justice for the population at large.

The Benih Mardeka newspaper was in a firm position concerning the political movement in East Sumatra, either as a mouthpiece or tool of Sarekat Islam. This was proven by the reports and coverage of every activity and congress carried out by this organisation at the central, branch and regions levels in East Sumatra. In addition, the editors and managers of the Benih Mardeka newspaper who were also administrators of the East Sumatra Sarekat Islam collaborated with other political movement activists in fighting for the interests and welfare of the native people in the fields of education, social and economy.

To defend the plantation workers, the editor of the newspaper Benih Mardeka together with the Sarekat Islam leaders directly visited the plantation workers to check on their conditions. In addition, the Benih Mardeka newspaper invited other newspapers, namely Pewarta Deli and Soeara Djawa, to raise funds managed by the Sarekat Islam and Boedi Oetomo organisations to help the plantation workers in East Sumatra. A serious defence measure was taken by submitting a resolution for plantation workers, which was presented at the central Sarekat Islam congress in Surabaya. 
Finally, the Benih Mardeka newspaper consistently played a role in its relations with the political movement and defence of plantation workers in East Sumatra. Although this took place in a relatively short period from 1916 to 1923, Benih Mardeka newspaper had become a pioneer in the national movement and the struggle for the rights of lower classes in East Sumatra.

\section{Acknowledgements}

The authors would like to thank the conference convener International Conference of Science, Technology, Engineering, Environmental and Ramification Researches 2018 for their benevolence during the conference of 2018 when the initial draft of this article was first presented. This research was funded by Direktorat Riset dan Pengembangan Masyarakat Kementerian Riset dan Pendidikan Tinggi Republik Indonesia (Research Directorate and Societal Affairs, Ministry of Research, Technology and Higher Education Republic of Indonesia) Scheme No. 78/UN5.2.3.1/PPM/KP-DRPM/2018, February 2018.

\section{Notes}

1. Currency used during this time was guilders $(f)$.

2. See MvO (Memorie van Overgave) van S. van der Plas aftredend Gouvernement Oostkust van Sumatra 1915.

3. In Staatsblad van Nederlandsch-Indie 1880 No. 133.

4. See AS GB-MGS (Algemeene Secretarie Seri Grote Bundel Missive Gouvernements Secretaris) $1890-1842$ No. 4268.

\section{Bibliography}

Adam, A. 2003. Sejarah awal pers dan kebangkitan kesadaran keIndonesiaan, 1855-1913. Jakarta: Hasta Mitra.

Anderson, B. 2008. Imagined communities [Komunitas-komunitas terbayang]. Jakarta: Insist Press-Pustaka Pelajar.

Anonymous. 1920. Overzicht van de Inlandsch-en Maleisch Chineesche pers 1920. Weltevreden: Drukkerij Volkslectuur. . 1918. Overzicht van de Inlandsch-en Maleisch Chineesche pers 1918. Weltevreden: Drukkerij Volkslectuur.

AS GB-MGS (Algemeene Secretarie Seri Grote Bundel Missive Gouvernements Secretaris) 1890-1842. No. 4268. Jakarta: Arsip Nasional Republik Indonesia (ANRI).

Benih Mardeka. 1920a. Bestuur-vergadering S.I. Medan Deli, 18 March. 1920b. Rentjana pekerdjaan dan keadaan S.I. Medan-Deli 1919, 31 March. 1920c. Koeli Contract dan S.I., 20 January. 1920d. Rentjana pekerdjaan dan keadaan S.I. Medan-Deli 1919, 25 March. 
1920e. Rentjana pekerdjaan dan keadaan S.I. Medan-Deli I, 27 March.

1920f. Koeli Contract dan S.I., 27 January.

1918a. Djedjak pertama, 20 August.

1918b. Pendahoeloean, 1 August.

1918c. Vereeningingen, 17 April.

1918d. Kelakoeannja werving-werving tengkoelak manoesia, 20 April.

1918e. Perkoenjoengan, 2 Mei.

Bezemer, T.J. 1921. Beknopte encyclopedie van Nederlandsch-Indie. 's-Gravenhage: Martinus Nijhoff.

Blumberger, J.T.P. 1931. De nationalistische beweging in Nederlandsch-Indie. Haarlem, Netherlands: H.D. Tjeenk Willink.

Breman, J. 1997. Menjinakkan sang kuli: Politik kolonial, tuan kebun, dan kuli di Sumatra

Timur pada awal abad ke-20. Jakarta: PT Pustaka Utama Grafiti.

De Sumatra Post. 1919. Tjokro Aminoto naar Medan?, 2 December. 1918. Voor de contract-koelies, 21 February.

Elson, R.E. 2007. Islam, Islamism, the nation and the early Indonesian nationalist movement. Journal of Indonesian Islam 1(2): 231-266.

Garraghan, G.J. 1957. A guide to historical method. New York: Fordham University Press.

Hoogerwerf, E.-J. 1990. Persgeschiedenis van Indonesie tot 1942: Geannoteerde bibliografie. Leiden, Netherlands: KITLV.

Janssen, C.W. and Bool, H.J. 1939. Senembah maatschappij 1889-1939. Amsterdam: Boek- en kunstdrukkerij v/h Roeloffzen-Hübner en Van Santen.

Kahin, G.M.T. 1995. Nasionalisme dan revolusi Indonesia, trans. N.B. Soemanto. JakartaSurakarta: Pustaka Harapan-UNS Press.

Korver, A.P.E. 1985. Sarekat Islam gerakan ratu adil. Jakarta: PT Grafitipers.

Locher-Scholten, E. 1992. The nyai in colonial Deli: A case of supposed mediation.

In Women and mediation in Indonesia, eds. S. Van Bemmelen, M. Djajadingrat-

Niewenhuis, E. Locher-Scholten and E. Touwen-Bouwsma, 265-277. Leiden, Netherlands: KITLV Press.

Loderichs, M.A. 1997. Medan: Beeld van een stad. Purmerend, Netherlands: Asia Maior. Mardeka.1920a. Mardeka, 1 April. 1920b. Kaoem boeroeh, 2 September.

. 1920c. Pemogokan kaoem boeroeh D.S.M. Sumatra Timoer, 4 September.

Middelbare Koloniale Landbouwschool Deventer. 1921. Arbeidswetgeving in Nederlandsch Indie (hoofdzakelijk voor het gewest Oostkust van Sumatra). Deventer, Netherlands: Drukkerij Davo.

Miksic, J.N. 1989. Urbanization and social change: The case of Sumatra. Archipel 37: 3-29. http://doi.org/10.3406/arch.1989.2558

$\mathrm{MvO}$ (Memorie van Overgave) van S. van der Plas aftredend Gouvernement Oostkust van Sumatra 1915. Jakarta: Arsip Nasional Republik Indonesia (ANRI).

Pelzer, K.J. 1985. Toean keboen dan petani: Politik kolonial dan perjuangan agraria. Jakarta: Sinar Harapan.

Reid, A. 2012. Sumatera: Revolusi dan elite tradisional. Jakarta: Komunitas Bambu.

Rutgers, F.L. 1939. Idenburg en de Sarekat Islam in 1913. Amsterdam: N.V. NoordHollandsche Uitgevers Maatschappij. 
Said, M. 1990. Koeli kontrak tempo doeloe dengan derita dan kemarahannya, cetakan ke II. Medan, Indonesia: PT Harian Waspada.

1976. Sejarah pers di Sumatera Utara dengan masyarakat yang dicerminkannya (1885-Maret-1942). Medan, Indonesia: Percetakan Waspada.

Said, T. 1987. Sejarah pers nasional dan pembangunan pers pancasila. Jakarta: C.V. Haji Masagung.

Samri, W. 2011. Medan press: National identity finding process. Historia International Journal of History Education XII(1): 185-207.

Schadee, W.H.M. 1917. Kroniek 1916. Amsterdam: Oostkust van Sumatra Instituut.

Serikat Perusahaan Surat Kabar. 1958. Sekilas sedjarah perdjuangan pers sebangsa. Jakarta: Serikat Perusahaan Suratkabar.

Staatsblad van Nederlandsch-Indie 1880 No. 133. Jakarta: Arsip Nasional Republik Indonesia (ANRI).

Stoler, A.L. 1983. In the company's chadow: Labor control and confrontation in Sumatra's plantation history, 1870-1979. PhD diss., Columbia University.

Soeara Djawa. 1918. Voorgadering S.I. Medan-Deli, 18 February.

Suwirta, A. 1999. Zaman pergerakan, pers, dan nasionalisme di Indonesia. Jurnal Mimbar Pendidikan 4: 83-94.

Szekely-Lulofs, M.H. 1985. Kuli. Jakarta: Gratipiers.

Van den Brand, J. 1902. De millionen uit Deli. Amsterdam: Boekhandel Hoveker \& Wormser.

Van Langenberg, M. 1976. National revolution in North Sumatra: Sumatra Timur and Tapanuli 1942-1950. PhD diss., University of Sydney.

Van Niel, R. 1984. Munculnya elite modern di Indonesia. Jakarta: Pustaka Pelajar.

Volker, T. 1923. Kroniek 1922. Amsterdam: Oostkust van Sumatra Instituut.

Volkslectuur. 1920-1931. Algemeene overzicht van de Inlandsche en MaleischeChineesche pers. Weltevreden: Volkslectuur.

Wertheim, W.F. 1987. Planters tegen koelis: Nieuwe studies over Sumatra's Oostkust. Bijdragen tot de Taal-, Land-, en Volkenkunde 143(2/3): 357-362.

Wie, T.K. 1977. Plantation agriculture and export growth: An economic history of East Sumatra, 1863-1942. Jakarta: LEKNAS-LIPI. 